DOI: https://doi.org/10.24127/ajpm.v9i1.2663

\title{
SELF EFFICACY TERHADAP KEMAMPUAN HIGH ORDER THINKING MATHEMATICS SISWA MELALUI PEMBELAJARAN BERBANTUAN SOFTWERE GEOGEBRA
}

\author{
Ratni Purwasih ${ }^{1}$, Ratna Sariningsih ${ }^{2}$, Indah Puspita Sari ${ }^{3}$ \\ 1,2,3 Pendidikan Matematika, IKIP Siliwangi, Bandung, Indonesia \\ E-mail: $\quad$ ratnipurwasih61@gmail.com ${ }^{1)}$
}

Received 26 January 2020; Received in revised form 07 March 2020; Accepted 29 March 2020

\begin{abstract}
Abstrak
Artikel ini merupakan hasil penelitian terkait kemampuan self efficacy matematis siswa SMP pada dua kelas. Penelitian ini bertujuan untuk mengetahui interaksi antara penerapan pembelajaran worksheet berbasis softwere Geogebra terhadap kemampuan self efficacy matematis siswa ditinjau kemampuan awal matematis (KAM) siswa. Melalui metode quasi eksperimen dengan desain pre test-post test, penelitian ini melibatkan 60 siswa SMP. Hasil penelitian menunjukkan adanya perbedaan peningkatan rata-rata kemampuan self efficacy matematis ditinjau dari kemampuan awal matematis (KAM). Hasil penelitian juga menunjukkan adanya peranan kemampuan self efficacy matematis antara kelas konvensional dan kelas eksperimen dari kemampuan awal siswa. Hal ini menunjukan bahwa peranan pembelajaran matematika berbasis softwere Geogebra mampu meningkatkan self efficacy siswa dibandingkan pembelajaran tanpa menggunakan softwere Geogebra.
\end{abstract}

Kata kunci: Berpikir matematika tingkat tinggi; geogebra; self efficacy.

\begin{abstract}
This article is the result of research related to the mathematical self efficacy of junior high school students in two classes. This study aims to determine the interaction between the applications of Geogebra software-based worksheet learning on students 'mathematical self efficacy abilities in terms of students' initial mathematical abilities. Through the quasi-experimental method with the pre-post-test design, this study involved 72 middle school students. The results showed a difference in the average increase in mathematical self efficacy abilities in terms of initial mathematical abilities (KAM). The results of the study also showed the role of mathematical self efficacy abilities between conventional classes and experimental classes from students' initial abilities. This shows that the role of Geogebra software-based mathematics learning can improve students' self-efficacy compared to learning without using Geogebra software.
\end{abstract}

Keywords: Geogebra; high order thinking mathematics; self efficacy.

\section{PENDAHULUAN}

Pendidikan matematika merupakan proses pembentukan pola pikir secara sistematis dan terstruktur. Melalui pembelajaran matematika, siswa memiliki kesempatan belajar kepercayaan diri, berani berpendapat dan proses berpikir. Pendidik memiliki peran penting untuk menciptakan pembelajaran yang efektif. Pembelajaran yang dapat menumbuhkembangkan kemampuan siswa lebih baik dari sebelumnya. Interakasi antar siswa dengan siswa, siswa dengan guru maupun siswa dengan lingkungan belajar merupakan proses pembelajaran. Proses pembelajaran matematika di sekolah harus memperhatikan bahwa matematika merupakan salah satu sarana pembentukan pola pikir siswa yang dapat diukur dari kemampuan. Matematika memfasilitasi cara berpikir manusia untuk memiliki kemampuan logis, kreatif, inisiatif dan kritis 
terhadap perubahan zaman (Sugiharti, Supriadi \& Andriani, 2019). Sehingga sudah jelaslah bahwa agar siswa memiliki kemampuan matematika yang baik, maka guru matematika sebagai faktor pendukungnya juga harus memiliki kemampuan matematika yang baik pula. Sejalan dengan tujuan pembelajaran matematika yaitu memiliki sikap menghargai kegunaan matematika dalam kehidupan yaitu rasa ingin tahu, perhatian, dan minat dalam mempelajari matematika, serta sikap ulet dan percaya diri dalam pemecahan masalah.

Siswa belajar secara bertahap demi tahap proses internalisasi keyakinan akan kemampuan diri untuk menyelesaikan permasalahan. Oleh karena itu, pembentukan aspek diri berkaitan dengan self efficacy memerlukan stimulus yang berkelanjutan. Self-efficacy dapat berupa bagaimana perasaan seseorang, cara berfikir, motivasi diri, dan keinginan memiliki terhadap sesuatu. Kemampuan pemecahan masalah matematik dapat dikuasai mahasiswa dengan baik jika mahasiswa menguasai kamampuan afektif, salah satunya adalah self efficacy (Sariningsih \& Purwasih, 2017). Salah satu faktor keberhasilan proses belajar adalah tumbuhnya suatu keyakinan dalam diri siswa. Seperti yang diungkapkan oleh Sariningsih \& Purwasih (2017) bahwa ranah afektif menentukan keberhasilan belajar seseorang. Ada lima karakteristik afektif yang penting dalam mempengaruhi hasil belajar peserta didik yaitu sikap, minat, konsep diri, nilai, dan moral. Self efficacy adalah believe atau keyakinan seseorang bahwa ia dapat menguasai situasi dan menghasilkan outcomes yang positif. Aulia (2018) menyatakan bahwa self efficacy adalah penilaian seseorang tentang kemampuannya sendiri untuk menjalankan perilaku tertentu atau mencapai tujuan tertentu. Menurut Aulia (2018) menyatakan bahwa self efficacy mengarah pada keyakinan seseorang terhadap kemampuannya dalam mengatur dan melaksanakan serangkaian tindakan dalam mencapai hasil yang ditetapkan. Fakta di lapangan, Self efficacy masih sangat rendah dikarenakan siswa yang tidak percaya akan kemampuan dirinya khususnya dalam pembelajaran matematika. Misalnya, kurangnya respon siswa untuk memberikan pertanyaan kepada guru dan menjawab pertanyaan dari guru. Hal ini disebabkan oleh beberapa faktor yaitu, siswa kurang memiliki keberanian dalam menyelesaikan soal-soal, rendahnya percaya diri, dan siswa cenderung menyerah menghadapi soal yang sulit.

Beberapa penelitian yang berkaitan dengan kemampuan high order thinking mathematics yang selanjutnya disingkat HOTM dan self efficacy melalui berbagai pembelajaran inovatif telah banyak diteliti seperti Hutagulung (2016), Siregar \& Sukatno (2017), Dinni (2018), Anwar \& Santosa (2019). Semua penelitian tersebut menyimpulkan bahwa ada peningkatan kemampuan high order thinking dan self efficacy siswa yang signifikan dalam proses pembelajaran. Kebaruan penelitian ini dengan penelitian sebelumnya yaitu kemampuan HOTM dan self efficacy ini melalui salah pembelajaran inovatif yang berbantuan softwere Geogebra. Sedangkan pada penelitian sebelumnya hanya menggunakan pembelajaran inovatif saja. Salah satu pembelajaran inovatif yang dipilih dalam penelitian ini adalah pembelajaran worksheet berbantuan softwere Geogebra. Pembelajaran ini 
memberikan kesempatan siswa untuk mengasah kemampuan penalaran dan problem solving. Penggunaan alat bantu dapat memebrikan kemudahan siswa belajar dan menstimulus gairah belajar siswa. Penggunaan alat peraga pembelajaran merupakan tugas guru untuk mendesain perencanaan pembelajaran di kelas. Sejalan dengan Sogo (2010) bahwa in our opinion, a more important barrier to the wider use of computers is teacher perception of the importance of an application, as well as teachers' proficiency.

Pembelajaran worksheet berbantuan Softwere Geogebra dapat membantu siswa belajar lebih aktif. Aripin \& Purwasih (2017) berpendapat bahwa lembar kegiatan siswa (LKS) berbasis alternative solutions worksheet (ASW) merupakan sebuah lembar kerja siswa yang menuntut siswa menjawab sebuah pertanyaan dengan lebih dari satu jawaban. LKS berbasis ASW dikembangkan untuk mendorong keterlibatan siswa dengan solusi alternative untuk masalah matematika selama pembelajaran (Aripin \& Purwasih, 2017). Pembelajaran Worksheet berbasis softwere geogebra menstimulus siswa berpikir kreatif untuk mencoba memberikan solusi terhadap soal. Pembelajaran worksheet berbasis softwere geogebra yang dimaksud dalam penelitian ini adalah pembelajaran melalui lembar kegiatan siswa (LKS) yang memadu siswa memahami konsep matematika melalui softwere geogebra untuk memberikan kesempatan siswa untuk mengeksplorasi kemampuannya melalui soal-soal bersifat open ended, dan juga melihat hubungan antara pengetahuan yang mereka peroleh dengan kehidupan sehari-hari. Proses mengeksplorasi ideide untuk menjawab berbagai soal matematika yang bersifat terbuka diharapkan dapat menimbulkan rasa ingin tahu. Proses dalam melihat hubungan dengan kehidupan sehari-hari akan berakibat siswa dapat menilai bagaimana aplikasi matematika pada situasi lain dalam pengalaman seharihari, dan memahami peran matematika dalam kehidupan sehari-hari. Penelitian ini bertujuan untuk mengetahui interaksi antara penerapan pembelajaran dengan menggunakan pembelajaran worksheet berbasis softwere Geogebra terhadap kemampuan Self efficacy matematis siswa ditinjau dari kemampuan awal matematis (KAM) siswa.

\section{METODE PENELITIAN}

Penelitian yang digunakan adalah penelitian quasi experimental dengan bentuk desain nonequivalent control group design, dimana subyek penelitian tidak dikelompokkan secara acak. Adapun desain penelitian yang digunakan pada penelitian ini adalah sebagai berikut:
A $\mathrm{O} \times \mathrm{O}$
Kelas eksperimen
A $\mathrm{O} \quad \mathrm{O}$
Kelas kontrol

dengan

A : acak kelas

$\mathrm{O}:$ Pretest - posttest

$\mathrm{X}$ : Pembelajaran matematika berbantu softwere Geogebra

Populasi dalam penelitian ini adalah seluruh siswa kelas VII sebanyak 7 kelas. Lokasi penelitian di SMP Negeri 2 Ngamprah, Kabupaten Bandung Barat. Sampel penelitian ini terdiri dari 2 kelas yaitu kelas VIIA sebagai kelas eksperimen dan kelas VIIB sebagai kelas kontrol masingmasing berjumlah 30 siswa. Kelas yang dijadikan untuk sampel penelitian dipilih melalui proses teknik cluster random sampling. Pembelajaran 
matematika di kelas eksperimen berbantuan softwere Geogebra dan kelas kontrol tanpa menggunakan software Geogebra. Intrumen penelitian ini adalah angket dan lembar observasi terhadap kemampuan afektif siswa yaitu kemampuan self efficacy matematis siswa. Angket dipergunakan untuk melihat respon siswa terhadap pembelajaaran sedangkan lembar observasi untuk melihat aktivitas siswa pada saat kegiatan belajar mengajar di kelas.

Instrumen penelitian ini adalah angket skala self efficacy yang berpedoman pada skala likert yang terdiri dari empat pilihan. Adapun indikator self efficacy yang digunakan dalam penelitian ini meliputi Magnitude (Bagaimana individu dapat mengatasi kesulitan belajarnya), Strenght (Seberapa tinggi keyakinan siswa dalam mengatasi kesulitan belajarnya), Generality (Menunjukan apakah self efficacy akan berlangsung dalam domain tertentu atau berlaku dalam berbagai macam aktifitas dan situas). Uji yang dilakukan dalam penelitian ini adalah: (1) uji perbedaan dua rata-rata untuk melihat (a) perbedaan self-efficacy terhadap matematika pada siswa yang memiliki kemampuan awal yang berbeda (tinggi, sedang, dan rendah), (b) perbedaan selfefficacy siswa yang berasal dari kelas yang berbeda (kelas A dan B); (2) analisis terhadap skor skala self efficacy untuk melihat apakah secara keseluruhan siswa memiliki selfefficacy yang positif terhadap matematika. Untuk keperluan analisis data maka siswa dikelompokkan dalam tiga kelompok pengetahuan awal matematika (tinggi, sedang, dan rendah). Pengetahuan awal matematika (PAM) mereka didasarkan pada perolehan nilai pretest soal matematika.

\section{HASIL DAN PEMBAHASAN}

Penelitian ini merupakan penelitian eksperimen dengan menerapkan pembelajaran matematika berbasis software Geogebra yang melibatkan dua kelas. Untuk lebih memudahkan dalam menganalisis data hasil skor KAM dan post test, berikut ini disajikan deskripsi statistik hasil skor KAM, postes, dan gain kemampuan high order thinking mathematics siswa pada kelas eksperimen dan kelas kontrol dalam bentuk Tabel 1.

Tabel 1. Statistik deskriptif hasil tes kemampuan HOTM.

\begin{tabular}{|c|c|c|c|c|c|c|c|}
\hline \multirow[t]{2}{*}{ Kemampuan } & & \multicolumn{3}{|c|}{ Kelas Eksperimen } & \multicolumn{3}{|c|}{ Kelas Kontrol } \\
\hline & & KAM & Post test & Gain & KAM & Post test & Gain \\
\hline $\begin{array}{l}\text { High Order } \\
\text { Thinking }\end{array}$ & $\overline{\bar{x}}$ & 1,06 & 8,24 & 0,26 & 1,08 & 6,912 & 0,29 \\
\hline $\begin{array}{l}\text { Mathematic } \\
\text { (HOTM) }\end{array}$ & $\mathrm{S}$ & 1,09 & 8,24 & 0,16 & 1,28 & 3,07 & 0,19 \\
\hline
\end{tabular}

Kemampuan HOTM siswa dalam setting pembelajaran berbasis software Geogebra dan konvensional disajikan pada Tabel 1. Sedangkan temuan tentang self-efficacy siswa disajikan pada Tabel 2. Berdasarkan data pada Tabel 1, ditemukan bahwa ditinjau secara keseluruhan, klasifikasi kemampuan awal siswa dan angka simpangan baku siswa kemampuan HOTM matematis dalam pembelajaran berbasis softwere Geogebra tergolong 
DOI: https://doi.org/10.24127/ajpm.v9i1.2663

kurang baik. Tabel 2 menggambarkan

berkaitan dengan pernyataan persentase jawaban hasil angket siswa

kemampuan self efficacy siswa

Tabel 2. Self efficacy siswa terhadap pembelajaran.

\begin{tabular}{|c|c|c|c|}
\hline \multirow{2}{*}{ Self Efficacy } & \multirow{2}{*}{ Indikator } & \multicolumn{2}{|c|}{ Skor } \\
\hline & & Kontrol & Eksperimen \\
\hline $\begin{array}{l}\text { Bagaimana individu } \\
\text { dapat mengatasi kesulitan }\end{array}$ & 1. Memiliki Pandangan yang positif & 2,93 & 3,12 \\
\hline belajarnya & $\begin{array}{l}\text { 2. Keyakinan terhadap kemampuan yang } \\
\text { dimiliki untuk mengatasi hambatan } \\
\text { dalam tingkat kesulitan tugas yang } \\
\text { dihadapi }\end{array}$ & 2,93 & 2,65 \\
\hline $\begin{array}{lll}\text { Seberapa } & & \text { tinggi } \\
\text { keyakinan } & \text { siswa } & \text { dalam }\end{array}$ & $\begin{array}{l}\text { 1. Komitmen dalam menyelesaikan tugas- } \\
\text { tugas yang diberikan. }\end{array}$ & 3,03 & 3,09 \\
\hline $\begin{array}{l}\text { mengatasi kesulitan } \\
\text { belajarnya }\end{array}$ & 2. Kegigihan dalam menyelesaikan tugas & 2,46 & 3,00 \\
\hline $\begin{array}{l}\text { Menunjukan apakah self } \\
\text { efficacy akan berlangsung }\end{array}$ & $\begin{array}{l}\text { 1. Dapat mengatasi segala situasi dengan } \\
\text { efektif }\end{array}$ & 2,86 & 3,15 \\
\hline 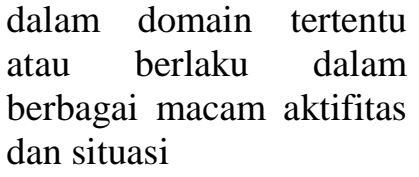 & $\begin{array}{l}\text { 2. Menjadikan pengalaman kehidupan } \\
\text { sebagai jalan mencapai kesuksesan }\end{array}$ & 3,23 & 3,14 \\
\hline Rerata & & 2,91 & $3, \mathbf{0 3}$ \\
\hline
\end{tabular}

Skala sikap yang diukur dalam penelitian ini adalah kemampuan self efficacy siswa melalui pembelajaran berbasis software geogebra. Analisis Tabel 2 menunjukan bahwa rerata kemampuan self efficacy siswa kelas eksperimen lebih baik dibandingkan dengan kelas kontrol. Hasil daru uji t perbedaan dua rerata menunjukan nilai signifikansinya adalah 0,012. Karena sig. $<0,05$ artinya kemampuan self efficacy matematis siswa di kelas eksperimen lebih baik dibandingkan di kelas kontrol. Hal ini menunjukan bahwa peranan pembelajaran matematika berbasis softwere Geogebra mampu meningkatkan self efficacy siswa dibandingkan pem-belajaran tanpa menggunakan software Geogebra. Pembelajaran menggunakan software Geogebra menumbuhkan rasa ingin tahu bagaimana proses konsep matematika dapat dipahami dengan baik. Hasil penelitian Pratiwi (2016) bahwa pembelajaran menggunakan software Geogebra mampu meningkatkan kemampuan pemahaman siswa.

Siswa terlihat antusias dan termotivasi untuk mengikuti pembelajaran matematika berbantuan softwere Geogebra. Selama pembelajaran berlangsung, siswa mencoba untuk menyelesaikan soal yang ada dalam worksheet berbantuan geogebra. Setiap kelompok pada saat diskusi membawa minimal satu laptop yang sudah di install software Geogebra. Hal ini bertujuan untuk memudahkan anggota kelompok berdiskusi dan menyelesaikan per- 
masalahan yang ada di worksheet tersebut.

Analisis selanjutnya adalah bahwa gender baik laki-laki maupun perempuan dan etnis tidak mempengaruhi kualitas kemampuan high order thinking mathematics siswa, namun aspek status sosial berpengaruh terhadap kemampuan self efficacy. Siswa yang memiliki status sosial kelas menengah ke atas lebih cenderung rendah daya juang dan motivasi untuk meraih prestasi sedangkan siswa dari kalangan status sosial kelas menengah ke bawah memiliki semangat juang yang tinggi untuk masa depan yang lebih baik.

Hasil pengamatan dan wawancara dengan beberapa siswa, menunjukan bahwa siswa yang tinggi kemampuan self efficacy-nya adalah siswa yang memiliki motivasi internal yang tinggi sehingga mampu menghadapi masalah menjadi suatu peluang. Menurut Hutagalung (2016) bahwa Siswa yang memiliki self efficacy akan memandang tugas yang sulit sebagai suatu tantangan dan cenderung akan mencari situasi yang baru dalam belajar, sehingga terhindar dari rasa jenuh ketika belajar. Peranan self efficacy penting sekali untuk mencapai sebuah cita-cita dan harapan. Karena, tanpa memandang kemampuan dasar yang dimiliki siswa, self efficacy merupakan kontributor penting untuk mencapai suatu prestasi. Kemampuan individu untuk mengatasi permasalahan dan menyelesaikan tugas serta mampu menghadapi hambatan-hambatan dengan tangguh dan pantang menyerah menandakan bahwa dalam diri individu itu tertanam self efficacy yang baik (Pudjiastuti, 2012).

Hal ini sejalan dengan Mareta \& Kusumawati bahwa Aspek self efficacy juga mencakup keyakinan terhadap kemampuan mengatasi hambatan atau masalah yang muncul, mengindikasi bahwa siswa harus berusaha dalam mengerjakan soal test dengan keyakinan terhadap kemampuan yang dimiliki untuk menyelesaikan dengan baik.

Pembelajaran di kelas berbantuan software Geogebra dapat merangsang siswa untuK mampu memvisualisasikan grafik secara tepat sehingga siswa memahami konsep persamaan garis lurus. Penggunaan Geogebra dalam pembelajaran akan membantu siswa dalam mengenal konsep dasar dari setiap konsep materi yang memerlukan visualisai atau animasi (Junaidi, 2018). Purwasih (2019), siswa akan terstimulus kemampuan berpikir kreatif matematis apabila diiringi oleh proses pembelajaran yang menunjang proses berpikir siswa terasah dan terarah. Penggunaan Geogebra memberikan fasilitas animasi dan gerakan manipulasi, program ini dapat membantu siswa memvisualisasi gambar kedalam dunia nyata. Dari hasil penelitian ini, implikasi yang didapatkan yaitu siswa menjadi tertarik dan mudah untuk mempelajari matematika.

Hasil penelitian ini sejalan dengan penelitian yang dilakukan oleh Widoratih, Enawaty, \& Lestari (2016) karena apabila peserta didik memiliki kemampuan berpikir kritis yang baik maka peserta didik tidak akan mengalami kesulitan dalam menyelesaikan persoalan konseptual matematika dan akhirnya hasil belajar peserta didik akan tinggi. Pembelajaran berbantuan software Geogebra membantu siswa mengenal konsep matematika dengan animasi yang ada pada tools. Penelitian Lusiana, Susanti \& Andari (2019) bahwa pembelajaran melalui media interaktif lebih menarik 
dan meningkatkan kemampuan siswa dalam memahami konsep yang diberikan oleh guru. Selain itu, Munandar \& Rizki (2019) juga menyatakan bahwa pemanfaatan teknologi komputer memiliki dampak positif dalam proses pembelajaran. Pencapaian self efficacy siswa melalui pembelajaran berbantuan softwere Geogebra tercapai dengan baik dan mampu menstimulus kemampuan HOTS siswa dalam memahami materi yang sedang dipelajari.

\section{KESIMPULAN DAN SARAN}

Dari hasil penelitian ini dapat disimpulkan bahwa siswa yang memiliki self efficacy yang baik lebih tangguh dan semangat dalam menyelesaikan permasalahan. Melalui pembelajaran worksheet berbasis Geogebra ini, proses berpikir siswa terstimulus untuk menyelesaikan tugas dengan baik dan siswa mampu memunculkan jawaban bervariasi. Berdasarkan penelitian yang telah dilaksanakan terdapat saran yaitu pembelajaan matematika berbantuan software Geogebra ini dapat di aplikasikan kembali ke level SD sampai SMA untuk menunjang proses kegiatan belajar yang lebih baik. Implementasi pembelajaran ini dapat juga materimateri berkaitan dengan bangun ruang baik di level SD, SMP maupun SMA.

\section{DAFTAR PUSTAKA}

Anwar, A., \& Santosa, R.H. (2019). Efektivitas Model Pembelajaran Tipe Team Assisted Individualization (Tai) Ditinjau Dari Prestasi Belajar Dan SelfEfficacy Matematika Siswa SMP. AKSIOMA: Jurnal Program Studi Pendidikan Matematika, 8(1), 4957.
Aripin, U., \& Purwasih, R. (2017). Penerapan Pembelajaran Berbasis Alternative Solutions Worksheet Untuk Meningkatkan Kemampuan Berpikir Kreatif AKSIOMA: Jurnal Program Studi Pendidikan Matematika, 6(2), 225-233.

Aulia, L. (2018). Peningkatan Kemampuan Komunikasi Dan Self Efficacy Matematik Siswa SMP Melalui Strategi Think Talk Write. Jurnal Numeracy, 5(2).

Hutagalung, D.D. (2016). .Hubungan Self Efficacy Dan Motivasi Belajar Dengan Hasil Belajar Matematika Siswa Kelas XI IPS SMA Negeri 5 Batam Tahun Pelajaran 2013/2014. Jurnal Mercumatika, 1(1), 34-43.

Junaidi. (2018). Meningkatkan Hasil Belajar Matematika Pada Materi Bangun Ruang Dengan Menggunakan Aplikasi Geogebra Di Smp Negeri 1 Mila. Jurnal Numeracy, 5(2), 184-193.

Lusiana, R., Susanti, V.D., \& Andari, T. (2019). Pengaruh Project Based Learning Berbasis Media Interaktif Terhadap Kemampuan Komunikasi Matematis. Aksioma: Jurnal Program Studi Pendidikan Matematika, 8(3), 354-361.

Mareta, Y. dan Kusumawati,D. (2014). Pendekatan Hands on Actifity melalui Modified Inquiry untuk Meningkatkan Self Efficacy Siswa Kelas XI SMAN TUBAN Pada Materi Pokok Laju Reaksi. Electronic Journal : Unesa Journal of Chemical Education, 3(1), 70-75.

Munandar, A., \& Rizki, S. (2019). Pengembangan Bahan Ajar Matematika berbasis Komputer Menggunakan Flipbook Maker disertai Nilai Islam pada Materi 
DOI: https://doi.org/10.24127/ajpm.v9i1.2663

Peluang. AKSIOMA: Jurnal Program Studi Pendidikan Matematika, 8(1), 262-269.

Pratiwi, D. D. (2016). Pembelajaran Learning Cycle $5 \mathrm{e}$ berbantuan Geogebra terhadap Kemampuan Pemahaman Konsep Matematis. Al-Jabar: Jurnal Pendidikan Matematika, 7(2), 191 - 202.

Pudjiastuti, E. (2012). Hubungan "Self Efficacy" dengan Perilaku Mencontek Mahasiswa. Jurnal Psikologi. Mimbar, 28(1),103-112

Purwasih, R. (2019). Kemampuan Berpikir Kreatif Matematis Siswa SMP dalam Menyelesaikan Soal Pemecahan Masalah di Tinjau dari Adversity Quotient Tipe Climber. AKSIOMA: Jurnal Program Studi Pendidikan Matematika, 8(2), 323-332.

Sariningsih, R., \& Purwasih, R. (2017). Pembelajaran Problem Based Learning Untuk Meningkatkan Kemampuan Pemecahan Masalah Matematis dan Self Efficacy Mahasiswa Calon Guru. Jurnal JNPM (Jurnal Nasional Pendidikan Matematika), 4(1), 163-177.

Siregar, Y.A., \& Sukatno. (2017). Hubungan Self-Efficacy Dan Sikap Positif Terhadap Prestasi Akademik Siswa SMK Negeri 1 Sipirok. MES (Journal of Mathematics Education and Science, 3(1), 22-29.

Šorgo, A. (2010). Information and Communication Technologies (ICT) in Biology Teaching in Slovenian Secondary Schools. Eurasia Journal of Mathematics, Science \& Technology Education, 6(1), 37-46.
Sugiharti, S.D., Supriadi, N., \& Andriani, S. (2019). Efektivitas Model Learning Cycle 7e Berbantuan E-Modul Untuk Meningkatkan Kemampuan Berpikir Kritis Peserta Didik SMP. AKSIOMA: Jurnal Program Studi Pendidikan Matematika, 8(1), 41-48.

Widoratih, K., Enawaty, E., Lestari, I. (2016). Pengaruh Model Learning Cycle 7E Terhadap Hasil Belajar Kimia Siswa Kelas X SMA. Jurnal Pendidikan dan Pembelajaran, 5(9). 